\title{
Review of Recommended Peaceful Projects and Contracts for Israeli-Palestine Conflict in Terms of International Rights
}

\author{
Abdolsamad Doulah $^{1} \&$ Mirshahbiz Shafee ${ }^{1}$ \\ ${ }^{1}$ Law Faculty, martyr Beheshti University, Iran \\ Correspondence: Abdolsamad Doulah, Law Faculty, martyr Beheshti University, Iran.
}

Received: October 22, 2015 Accepted: June 17, 2016 Online Published: July 31, 2016

doi:10.5539/jpl.v9n6p151

URL: http://dx.doi.org/10.5539/jpl.v9n6p151

\begin{abstract}
Israeli-Palestinian conflict is one of the most complex and longest conflict in history. The problem which officially recognized with UN resolution 1947 and creation of two countries, was the initial point of consistent and continuous conflict. This is the beginning of wars, creation of movement, contracts and peace projects. Mentioning these contracts and plans and investigating the importance of its provisions could answer to the lack of permanent peace as well as the most important cases of parties. Some of these projects include the Camp David proposal, Fahd, Fez, Reagan, Mubarak, Madrid, Oslo, Maryland, Sharm el-Sheikh. Each one ,according to political and its historical position is accepted, rejected, or partially accepted by the parties that led to the creation of the conditions and obligations for the parties of the conflict. Despite all the peace plans and agreements, parties did not agree on a comprehensive plan for the establishment of lasting peace in the region the In fact, it seems as long as there is no determination beyond the interests of the Palestinian-Israeli groups and parties there, getting to the ultimate goal which is the sustainable peace, is elusive and this destructive cycle of war and peace will continue.
\end{abstract}

Keywords: Israeli and Palestinian conflict, contracts and peace plans, conflicts, permanent peace, interest of groups and parties

\section{Introduction}

By the termination of World War II, world have witnessed a new international discipline, resulted foundation of United Nations Organization. The organization which was formed based on the purpose of protecting peace and prevention of war, has structured one of the long-lasting conflicts during second half of 20th century, continuing till present. In fact, the issue of Palestine conflict has been one of the long-lasting conflicts during 20th century. Palestine was an issue for UN and Security Council that has made challenges peace and international security. In 1947, Statement 181 of UN has been submitted by Genral Assembly. Based on this statement, two countries of Palestine and Israel officially have been recognized and from the time, this conflict has been continued till now, including years 1948, 1956, 1967 and 1973 some wars have been happened as the climaxes of such crisis.

In 1979, 348 experienced Israeli officers, in a letter to Menachem Begin (sixth prime minister of Israel), have reminded the necessity of peace significance to him. This letter, signed by a group of experts and participants in Israel military, according to one of the famous officers named Yoval Neria, who has achieved Medal of Valor (for his effective participation in War during 1973), was written to reflect the request of Israel citizens for making peace and termination of conflict to governors. In a short while, this letter has became a civil rights movement and it was the beginning of movements for making peace in regime, such movements caused peaceful movements like present movement of peace, Gush Shalom movement, Betslm center, and ... in Israel. The author, in this letter has reviewed the attempts in forms of plans and contracts for solving such world conflict.

\section{Projects Proposed in the Palestinian Conflict}

By submitting statement of year 1947 UN , Israel officially introduced itself as a country and from the time, we have witnessed conflicts causing four major wars between Arabs and Israelis. One of the significant results of War in 1967, was the issue which Israeli-Palestinian conflict became Arabic. It means mentioned war caused the occupation of some areas of Arab countries in addition to whole lands of Palestine by Israel. Therefore, from the time after, several plans and conferences have been held in order to provide peace and resolution for conflict among Arabs and Israelis; although, none of them have any useful result. Below, most significant projects during 
cold war $^{1}$ and afterwards will be introduced:

\section{A: During the Cold War \\ - Fahd peace plan}

Fahd, Principe herdeiro of Saudi Arabia in 1981, has provided a plan including 8 provisions as the basis of Middle East Peace in order to resolve the conflict between Arabs and Israel and also to check the status of Palestinian. This plan includes:

- Israel retreats from all the borders occupied in 1967. Including Arabic-populated part of Jerusalem;

-Dismantling Jewish towns constructed in 1967 and after that in Arabs areas;

Freedom of pray for all kinds of religions in holy places;

-Insisting on Palestinian rights for returning to their homes and pay to those who are not preferring to come back home;

-Considering a transferring period for West Bank and Gaza, not exceeding from some months;

-Founding an independent Palestinian country, Jerusalem must be its capital;

-All the countries can live together in peace;

-guarantee of UN for execution of the mentioned provisions; ${ }^{2}$

Based on International rights, Israel has had the occupying force in these occupied lands. Future incidents in such lands have not changed the situation.

Regarding recognizing Israel as occupying power and also the insist of Genève conventions and additional protocol (Israel has signed them) relating to actions like transferring a part of non-military population of occupying government to occupied area by the government, dismissal or transferring whole or a part of occupied areas population, non-excused delay for returning prisoners of war or non-military people to their homeland, racism and similar actions, attack to historical places, art works or holy places are vivid breach of Genève convention and its additional protocols.

Therefore, regarding internal rights, Israel has been forced to accept this plan and retreat to the borders before 1967 and must stop constructing towns and must give the right to Palestinian to return to their homeland and pay them for the compensations and regarding article 1 of Covenant on civil, political, economic, social and cultural rights that vividly support the right for determining destiny to provide opportunity for implementation of a Palestinian independent government. However, Israel has rejected such plan.

\section{- Foss Plan}

After Israel assault in Lebanon, during Conference of Heads of Arab in November 1981 and September 1982, a nine-provision plan has been published by twenty countries of United Arabs in Foss. This plan can be called Fahd plan with only one different provision. The fourth provision of the mentioned plan, instead of mentioning the return of Palestinian to their homes and paying compensations to them; it is claiming the autonomy and inevitable rights of Palestine by the leadership of Palestine freedom organization, as the only legal agency of Palestinians. Regarding the responsibility of Israel as the occupying power, this government has obliged to fulfill the international reliabilities, but such obligations must be done regarding the assurances and obligatory principles of conventions and approved protocols by this country. But since powerful countries are supporting this strategic partner like U.S in UN, Security Council and other international committees (such supports are including vivid and hidden veto by US or other western and European countries in Security Council), have suppressed the probability of putting pressure on Israel for fulfilling its reliabilities and the principles. If Israel was not supported by powerful countries, it would obey the principles and the accepted conventions and as a result, Israel would sign the plan, unfortunately regarding such supports, Israel has rejected such plan. ${ }^{3}$

\section{- Reagan peace plan}

During the early of 1980s and following the submit of Camp David treaty, by mediation of US in 1982, and Israel attack on Lebanon, Ronald Reagan has presented a peace plan as follows:

\footnotetext{
${ }^{1}$ The Cold War began from 1947 and ended in 1991 with the collapse of the Soviet Union.

2 ofsky, George, American and the Middle East presidents, translated by Abdolreza Houshang Mahdavi, Alborz publication, 1994 , p. 388.

${ }^{3}$ Ghannouchi, Rashid, the issue of Palestine and nature of the Zionist plan, translated by Saeedeh Khorooshan, Islamic Publications Office, 1991, p. 31
} 
- Autonomy of Palestinian living in West Bank and Gaza; before autonomy, a transferring period will be passed to show that Palestinians are able to manage their affairs and their autonomy will not be a threat for Israel;

- During transferring period, US will not support Israel for using lands for constructing Israeli towns;

- Independent Palestinian government will not be formed, but peace will not be achieved based upon Israel dominance or permanent dominance on West Bank and Gaza;

- Autonomy of Palestinian in West Bank and Gaza with collaboration of Jordan will be the best solution for peace-making

- Jerusalem will remain undivided. ${ }^{4}$

This plan will ignore the rights of Palestinians like the right for return to their homes, being paid for compensations. In addition, it violates the right for determining the destiny of nations to some extent, since it does not allow forming an independent government for Palestinians, but it provides the right of autonomy in West Bank and Gaza to some extent. However, it has some innovations in comparison with previous plans; including forbidding US supports for constructing Jewish towns and Jerusalem will remain undivided, such conditions put more pressure on Israel for obeying human rights and recommended principles by International rights. Of course, the parties do not accept this plan.

\section{- $\quad$ After the Cold War}

\section{Mubarak plan}

Mubarak plan was to hold elections within occupied areas in order to elect people as the representatives of Palestinians for negotiations with Israel. His plan was as follow:

That is the right of every person in Judea and Samaria (including East Jerusalem) and the Gaza Strip, to participate in voting and pose themselves as candidates;

- Freedom of struggle either before or during the election;

- Acceptance of international monitoring of the electoral process;

- Providing formal commitment from the Israeli government to accept the election results;

- Withdrawal of Israeli armed forces from areas of election, before the election;

- Preparation for election implementation by Israeli-Palestinian committee;

- Guarantee of all items raised by the United States;

- stopping settlement activities of the Israeli government .

This plan is accepted and rejected in Israel and practically their viewpoints have been divided into two ${ }^{5}$.

This plan has not been concluded due to considering freedom of elect for Palestinians and Israel obligation to obey Genève convention about discontinuing settlement in occupied areas and US guarantee to do such reliabilities by Israel and practically for the lack of vision and political integrity in both Palestinians and Israeli sides.

\section{- Arabic Peace Plan}

In March 2002, King Malek Abullah of Saudi Arabia, has provided a plan along with last two decades attempts of Riyadh in UA meeting in Beirut, it is called Arabic Peace Plan. This plan is submitted in absence of Yasser Arafat, president of the Palestinian authority. Due to this plan, Israel must retreat to the borders according to year 1967 and on the other hand, Arab World must know Israel as an official country. But Israel didn't take part in such negotiations due to that they were not accepting to come back to the borders of year 1967 and they didn't consider any official right for Palestinians. On Palestine side, the Plan by Malek Abdullah has faced with a fundamental challenge due to the victory of Hamas in election of 2005. Since the policy of Hamas was based on battle and vanishing Israel and it has fundamental problem with the existence of Israel even within the borders of year $1967^{6}$.

\footnotetext{
${ }^{4}$ OFsky, George, a priori, p. 390

${ }^{5}$ Flamhaft, Ziva, Israel on The Road to Peace, West view Press, United State, 1996, p 67-68.

${ }^{6}$ The student news agencies, 2014, resistance - negotiation the dual permanent history, 03.08.1393, the student news agency website, available at the address: http://snn.ir/detail/News/358579/9022(17:30)
} 


\section{- Road Map Peace Plan}

The map of the way is the plan provided in 2002 by EU and after the success of Intifada. This plan was quadripartite and UN, EU, Russia and US was responsible for the progress of this issue. Of course, Bush speech in June 24th 2002, which is seemed to be written by Sharon, ${ }^{7}$ was about resignation of Arafat and also to stop Palestinians violence as the preconditions for any future negotiation with Palestinians. ${ }^{8}$

Anyway, this project has three phases that the first phase has two steps:

First phase: November 2002 to May2003 (transitional phase / election)

The first stage: October-December 2002

- The formation of the Palestinian government and choose a prime minister with the necessary powers;

- The Palestinian Legislative Council, elected a committee to draft a constitution;

- Palestinian leadership, recognize right to live in peace and security for Israelis with the publication of sharp statement and demanded an end to the armed intifada and acts of violence against Israelis in everywhere;

- All Palestinian organizations will stop any kind of incitement against Israel;

- The state of Israel stops all acts, including attacks on urban areas, destruction of houses, the confiscation and destruction of Palestinian property and their deporting that damage to trust of the parties, and ends the construction of settlements in the Occupied Territories ${ }^{9}$

-The state of Israel destroys all residential areas built during the present government,

\section{First phase: January May 2003}

- Independent committee, publishes the Palestinian constitution which is based on principles of parliamentary democracy is to be revised and examined;

\section{- Establishing a monitoring tool by the International Quartet;}

-Palestinians practice the request of quadripartite committee in field of economic, legal and administrative.

-By the increase of security cooperation, Israel must retreat from the occupied areas after September 28th 2000, and it must be done before Palestine election.

- Israel government re-opens chamber of commerce in Jerusalem and also other Palestinian commercial institutions in east of Jerusalem.

- Israelis and Palestinians will sign a new security agreement including founding an efficient security tools to stop terrorism, violence and stimulation. ${ }^{10}$

- Israel government shall stop all the activities relating to settlement including natural flow of people settlements.

- Palestinians will hold a free and valid election for selecting the members of law-making council.

-When Israel comes back to its borders based on September 28th, Jordan and Egypt will send their ambassadors to Israel. ${ }^{11}$

\section{Second phase: June-December 2003}

-Quadripartite committee, after announcing the results of Palestine election, will hold an international conference in order to rebuild Palestine economy and starting negotiation about founding a Palestinian government within the temporary borders.

-The negotiations of Israel and Palestine about forming a government within temporary borders and execution of previous agreements and continuing regional cooperation in this regard will be held

-Avoiding temporary residence and forming a government within temporary borders until end of 2003

- Another activity for resolving the related issues to founding temporary government

\section{The third phase: 2004 to 2005}

\footnotetext{
7 Venkateshwar Rao Jr., Parsa, India's Right- Wingers Woo Jewish Lobby, Daily Star (Beirut), 20 May 2003.

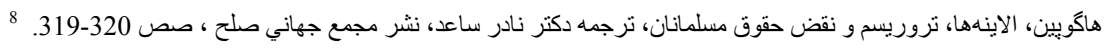

${ }_{9}^{9}$ Whitbeck, John, The Road Map, Daily Star (Beirut), 4 May 2003.

${ }^{10}$ Both Quotes Are in Ali Abunimah, "Who's Afraid of the Road Map?" Daily Star (Beirut), 2 May 2003.

${ }^{11}$ Statement From Prime Minister's Bureau, as Released by Israel's Government Press Office, Israel Accepts 'Steps' of Road Map, Qualified by Remarks, Israel Insider, 25 May 2003; http://www.israelinsider,com(21:50).
} 
-Holding second international conference: quadripartite committee, by the confirmation of parties in beginning of 2004, holds an international conference for achieving an agreement about the existence of Palestinian government within temporary borders and the negotiations of Palestinians and Israelis will become an agreement in 2005, such agreement includes the issue of borders, Jerusalem, refugees and support for finding solutions for disputes among Israel, Lebanon, Syria and also Jerusalem. ${ }^{12}$

-This plan has got its specific features that distinguish it from other plans. First, this peace plan is approved by Quadripartite committee including US, EU, UN and Russia and based on international relations, and not international rights, it is internationally legitimated. Second, it has specific and accurate timing forecasted for execution of different parts of the plan. Third, the Plan is designed for execution. Unlike previous plans, in this plan, the duties of parties were vividly determined and both parties were obliged to obey them and at the end, the plan was having enforcement, in a way that, from this quadripartite committee, a supervisory group was formed to confirm the fulfilling of the reliabilities and duties of the parties. ${ }^{13}$

But this plan, despite all of its new features, has been neglected due to different reasons. First reason, the main designer of the plan was US. Many of political and military critics believed that introducing this plan for resolving the crisis in Israel and Palestine, regarding to the conditions at that time, was only a temporary plan from White House, only to draw the attention of the world to this issue, away from illegitimate war in Iraq. Second reason of failure of this plan was due to Israel. Ariel Sharon government has announced that, this plan can be successfully done if we do fourteen changes in it, and such preconditions must be considered in this plan $^{14}$. Ultimately, Palestinians were named as the last failure of this plan. Suicide attack of Palestinians in August 19th of the year to the bus in Jerusalem and the Israel feedback to this attack and also resignation of Mahmud Abbas have provided the total failure of this $\operatorname{plan}^{15}$.

\section{The Contract and the Draft of the Peace Agreements}

Totally, contracts and drafts of peace contracts can be divided into three specific periods. First period, that only includes Camp David treaty and caused fission in Arab World for battle with Israel. Second period, including 1990s, in this period, the US, after Soviet collapse, as the only power in the world, was having a crucial role in negotiations, in such decade, many negotiations and contracts have been formed and world society was highly active for finding solution for Israel and Palestine. Third period is started from year 2000, includes some of the most important effective features interfering on such conflicts; including the strength of Sharon in Israel, the escalation of Intifada and 22 day war in Gaza.

\section{- First course}

\section{The Camp David Agreement}

After War in 1973, USA had an effective role within peace conferences relating to Middle East. This issue, due to the economic benefits (oil) of US in Arab countries, its reliabilities towards keeping Israel security as its strategic confederate, prevention of soviet penetration among Arab countries and holding initiative in Middle East peace plans, turning point of peace flow among between Arabs and Israel shall be searched during last years of 1970s and signing Camp David treaty between Israel and Egypt. Menachem Begin and Anor Sadat have met Jimmy Carter in Camp David and after negotiations, they have signed peace treaty. At that time, based on the provisions of Camp David treaty, in order to be succeeded in peaceful relations based on the spirit of article 2 of UN Charter, future negotiations among Israel and each one of its neighbors that come to that country for peace, in order to execute all the conditions and the principles of Resolutions 242 and 338, was considered a necessary issue

Egyptian cabinet in September 19th, have confirmed Camp David treaty and Also Kanset, on September 28th with 84 votes, against 19 votes and 17 abstentions, has confirmed it. Camp David treaties provided more negotiations and signing peace treaty between Egypt and Israel. In fact, the most important event in 1978, in relations between Israel and Egypt is Camp David treaty. Following the signing of the treaty Anwar Sadat was

\footnotetext{
${ }^{12}$ knesset, A Performance- Based Roadmap to a Permanent Two- State Solution to the Israeli- Palestinian Conflict, 2003, website knesset, 4 September 2014; Available at URL: http://knesset. gov.il/ process/docs/roadmap_eng. htm (16:37).

${ }_{13}$ Asadollahi, Masoud, plan and road map for Middle East Peace Strategic Studies, Issue 21, 2003, Page 49

${ }^{14}$ Bina, the United States obstacle to peace in Palestine, Ebtekaar newspaper, Issue 1574, 26 September 2009

${ }^{15}$ Sajjadinia, Ali, the fate of the Middle East peace roadmap after the fall of the government of Mahmoud Abbas, in 2003, the website of Radio Farda, 3 Persian date Shahrivar 93, available on the address:

http://www.radiofarda.mobi/a/358188.html(12:56).
} 
assassinated by Khaled Eslamboli and Egypt was expelled from the Arab community. ${ }^{16}$

This Agreement caused disruption of Arab unity to support the Palestinian. As a result of the agreement and in the years after the conclusion of this agreement, Egypt complicated possibility of the various relief which one of the most important ways of pathways was related to Egypt by closing pathways related to Palestine such as Rafah crossing, which was the blockade of Gaza by Israel. This is the crime against humanity. In addition, it threatened freedom of movement and physical and financial security, and Palestinians, especially Gaza Strip. This would violate human rights and fundamental freedoms such as the right to life, right to freedom of movement, freedom of belief and religion, and it caused to violations of international humanitarian. ${ }^{17}$

The negotiations still remained despite the regime change in Egypt and the rise of Morsi's government. Although whisper was heard to cancel the agreement and regime change was known on legal basis for it, but with the advent of the military and exit of Morsi from power this as not done and Camp David Accords remained to its former validity.

\section{Second course}

After comfortably surviving Persian Gulf War (1991), George HW Bush summarized the image from the new order in the Middle East in four objectives:

- Creating common security arrangements in the region that means America's participation in common military training of ground and air forces and the effective presence of the United States Navy in the region:

- Supervisor of spread of weapons of mass power and their carrier rockets;

- creating new opportunities for peace and stability in the Middle East by ending the Arab-Israeli conflict and their problem-solving with Palestinian which, according to Bush, the United Nations Security Council Resolutions 242 and 338 and the principle of land for peace must be its foundation

- Supporting economic development for achieve peace, progress, freedom and prosperity for all nations in the region.: ${ }^{18}$

Within the framework of the implementation of the new order in the Middle East, certainly, it must be said that the settlement of the Arab-Israeli conflict had formed an important part of America's policy; Because if it was supposed to form new order in region, the issue needs to be solved. Therefore, efforts were made which were a precursor to negotiations and peace agreements. After the collapse of the Soviet Union, the Middle East have changed and it was considering that a new Middle East is emerging. Some of the factors; that prompted the Palestinians to declare readiness to compromise with Israel include:

-failure of Palestinian groups in strategy of armed struggle with Zionist regime and reach the conclusion that the destruction of the State of Israel and formation of an independent Palestinian state by military means is not possible;

- The uncertainty of the PLO (Palestine Liberation Organization) to Arabic countries in serious efforts to resolve the Arab-Israeli conflict and problem solving of the Palestinian as a problem and a political tools is in the hands of the Arabic countries and none of the Arabic countries are present to lose their interests against Palestinian problem. In fact, the PLO already concludes that Palestinian issue as a problem and a political tools was in the hands of the Arabic countries and none of the Arabic countries were present to lose their interests against Palestinian problem solving.

-The Palestine Liberation Organization support from Iraq during occupation of Kuwait and supports from the organization during the Persian Gulf War, had created significant problems for Yasser Arafat. This position also led to the expulsion of Palestinians from the Persian Gulf Cooperation Council countries, which caused the loss of a significant portion of their income and the displacement of a large number of Palestinians. It also causes cutting off financial aid and political support of Arabic countries to the PLO . So that this organization was facing financial and political crisis;

- The development and continuation of the intifada as a completely new movement had started and continued, by the two main groups of Islam, means Palestinian Islamic Jihad and Hamas, had engulfed Throughout the Gaza

\footnotetext{
${ }^{16}$ Abdollahi, Ismaeil , Zibaei, Mehdi, Israeli strategic assessment, the Institute of Contemporary Abrar International Studies, Volume I, 2002, p 406

${ }^{17}$ Fars News Agency, 2015, closing the Rafah crossing, crimes against humanity, Fars News Agency website, available at the address: http://www.farsnews.com/newstext.php?nn=13921228000019, 28/12/92, (20/7/94), 14:30.

${ }^{18}$ Flamhaft, Ziva, op.cit, p 77
} 
Strip and West bank, on the one hand, make the Zionist regime poor and on the other hand had reduced legitimacy of the Palestinian leadership by the PLO.Therfore, the PLO started to compromise with Israel to seize the initiative, to stabilize the situation and their political survival and coming to power as Palestinian leader

-Finally, the collapse of the Soviet Union as the greatest traditional supporter and international umbrella of Arabs in the Arab-Israeli conflict, severely limited the International political movements and some Arabic countries and the PLO as well. It also deprived them from financial and military support of East superpower. ${ }^{19}$

\section{-Madrid Peace Conference}

Peace plan with the slogan of land for peace, was the turning point of George Bush $\mathrm{Sr}$

peaceful efforts, the incumbent president of the United States. The first round of talks in Madrid in October 30, 1991 began by the attending of delegations from Syria, Lebanon, Israel and the Palestinians -Jordan common Committee. In the opening session, the President of the United States, the former Soviet Union and the Prime Ministers of Spain and Israel delivered speeches. Israeli Prime Minister Yitzhak Shamir, opposed the land for peace in this lecture and he emphasized that will not ignore occupied territories and will not stop construction of Jewish settlements. there was no special event up to fifth round of talks in Israel that the Likud Party was reigned. But in the sixth round that the Labor Party led by Yitzhak Rabin came to power in Israel, the peace talks witnessed new slogan of Robin. Robin with accusing the Likud Party stating that it impede the progress of peace negotiations, announced that he accepted resolutions 242 and 338 but he rejected withdrew from southern Lebanon in accordance with Security Council resolution 425. And he subjected this withdrawal to guarantee the security of Israel from Lebanon and to disarm and destroy Hezbollah. Israeli Prime Minister announced the continuation of settlements, makes the negotiation process longer. So the settlement will be stopped. Nevertheless, contrary to this, the settlement policy and the lack of implementation of Security Council resolutions continued as before. Moreover, the continuation of negotiations does not produce a result. Madrid peace talks after eleven rounds did not reach to a final decision and it virtually reached a dead end. ${ }^{20}$

\section{- Gaza-Jericho Peace Agreement (Oslo 1)}

Along with the multilateral negotiations between Arabs and Israelis representatives that did not reach to clear conclusion after eleven rounds, bilateral talks between the main parties the PLO and Israel was secretly in continue in Oslo capital of Norway. Numerous bilateral talks, eventually led to the signing of contracts between the PLO and Israel with the sign of Yasser Arafat head of the PLO and Israeli Prime Minister Yitzhak Rabin or their representatives. the contract "Gaza-Jericho" or contract "Oslo 1" the first peace treaty between the PLO and Israel, considered as the beginning of limited autonomy with Palestinian authority in a small part of occupied territories. The final document of this Agreement signed by Yitzhak Rabin and Yasser Arafat in Washington on 13 September $1993 .^{21}$

The formation of a governing council to manage the Authority was predicted in Israeli plan. Accordingly, the mentioned council was responsible for the majority of administrative tasks, economic, agricultural, service, health, education, tourism and the establishment of General Courts in the Gaza Strip and the Judea and Samaria (after the development of Authority in Judea and Samaria)

Mentioned Council has no legislative powers and did not have the right to decide on security issues and foreign policy . The council also was not authorized to prevent construction of housing units in settlements and also didn't have the right to intervene in current affairs. In other words, this project was only limited participation in the government not Israeli sovereignty transfer. It also considered Jerusalem issue unassailable. Jerusalem in the project, remain integrated and eternal capital under Israeli sovereignty and in this regard no compromise would work., a month and a half after the signing of the Gaza-Jericho, Yitzhak Rabin declared Jerusalem will remain the united capital under Israeli sovereignty. ${ }^{22}$ Very limited autonomy on the part of Palestinian lands without recognize Palestine, is the only thing that can give from Israeli officials to Palestinians, which is also subject to conditions, including the prevention of suicide bombings and violent of Palestinian militant groups .and the security of Israel and Jewish citizens by the authority. Conditions that made appeared the authority in the role of a gendarme and the Israeli police. This concept can be understood in a statement of Faisal Husseini, head of Palestinian negotiator board. A few days after the signing of the Gaza-Jericho he said: Palestinian-Israeli

\footnotetext{
${ }^{19}$ Soleimani, Mohammad Bagher, players of Middle East Peace Process, Institute for Political and International Studies, 2000, pp. 41-40

${ }^{20}$ the same.p 32

${ }^{21}$ Bina, selected of the event, the Middle East Quarterly, first year, number one, 1994, p 129

${ }^{21}$ the same .p 214

${ }^{22}$ the same .p 214
} 
agreement does not end in to a Palestinian state, but we have to look at the world according to the current situation. $^{23}$

\section{- Taba peace agreement (Oslo 2)}

The second round of negotiations that is known as Taba Agreement or (Oslo 2), covers the continuation and expansion of the Palestinian Authority in Judea and Samaria. The final document of this agreement was signed by Yitzhak Rabin and Yasser Arafat in Washington in September 28, 1995 . This document sets out five main chapters in relation to the necessary arrangements for Palestinian legislative elections and the other different items. the main elements of this agreement include the following:

- doing arrangement for transferring control of six cities and towns of the West Bank and the surrounding Arab villages to the Palestinian Authority and carry out the necessary arrangements for the forthcoming withdrawal of Israeli forces from Hebron and carrying out the security arrangements in the city;

- The division of the West Bank and Gaza Strip into three regions;.

A: areas that need to be fully assigned to the Authority; for the temporary period of autonomy

(B) area that is common between Palestine and Israel in terms of judiciary;

C: An area, which remains in full control of Israel and, will gradually be transferred to the Authority, except for areas that are vital for Israel's security;

- carrying out the necessary arrangements for the election of the Palestinian Legislative Council;

In this treaty also stipulated that further setbacks of Israeli military forces to specified military locations, based on the terms of reference agreed in Oslo Declaration will carry out in third step. These stages begin each for 6 months after the start of the Palestinian Legislative Council and end within 18 months after this date. ${ }^{24}$ What the Palestinians in these agreements obtained is a series of municipal responsibilities that are outside of Israeli control. And what Israel obtained is the satisfaction to continued occupation the Palestinians . Israel has transferred its only location of its troops from major Palestinian city in the West Bank to the suburbs except Hebron. Israel has monitored outgoing and incoming entries and all roads leading to the cities of the West Bank Palestinians are responsible for the cities function and approximately 400 villages through Israeli security belt. But the real responsibility for security, resources or areas outside of the population centers was for Israel and have no right to interfere in the affairs of immigrants, police and the Israeli army. Israel also has the effective monitoring all affairs of areas including security, water, land, air space, radio waves, roads, borders, etc. ${ }^{25}$

\section{There are many criticisms of the Oslo agreements. The most important of these criticisms are as follows:}

-This contract has temporary nature and must make a way for permanent agreement, but after more than 20 years, it did not become permanent contracts;

-The temporary nature of this agreements, was given the possibility to regulators to refrain from some basic issues which should be applied to their limits. Issues such as borders, settlements, refugees, security and Jerusalem.

- While it said that Palestinian negotiators during this interim period of 5 years, tried to suspend the construction of all settlements of the Zionist regime, but they failed to do the same commitment and over two decades of the Oslo accords, the number of settlements has doubled;

- Jerusalem, was one of the issues that its fate was postponed and in this contour, isolated contexts of the city accelerated with walls and checkpoints;

- One of the weaknesses of this treaty, is the lack of enforcement mechanisms. If any of the parties fails to perform their obligations, no solution was considered to the problem. Although this agreement was signed in Washington, but no third party has guaranteed he efficiency and accurate and complete implementation of the deal. And if one of the parties of this agreements violate his obligations, he will not include any penalty.

- Another issue was Israel's separation wall. Since there was no reference to Israel's security wall in the Oslo Accords, , in the absence of an agreement on the border, Israel, illegally could build a wall in the Palestinian territories. Although the Palestinians have brought this issue to the Hague court, Israel didn't accept an advisory

\footnotetext{
${ }^{23}$ Bina, the Gaza-Jericho Full text draft contract, Middle East Quarterly, first year, number one, 1994, p. 211

${ }^{24}$ Abdullahi, Ismail, Zibaei, Mehdi, a priori, pp. 108-107

${ }^{25}$ Said, Edward, Mirage of Peace (of Oslo one to Oslo II), Middle East Quarterly, the third Issue, 1995, pp 998-997.
} 
opinion court on the illegality of this wall and did not destroy it. ${ }^{26}$

\section{- Maryland contract}

Following the assassination of Yitzhak Rabin by Yigal Amir, a Jewish extremist, in 1995 Israeli elections were held in 1996 in which the right-wing Likud party candidate Benjamin Netanyahu defeated his rival candidate, Shimon Peres of the Labour Party. According to Likud's views on the Middle East peace process, which is mainly the result of extremist religious Zionist movements and the pro-military force to achieve political goals, with the advent of the Netanyahu government, despite his commitment to the Middle East peace process, the Israeli government stopped the Palestinian land demands which were being emphasized at the Oslo conference, and turned the Israel's security to a top priority. Netanyahu put principles of reciprocity, security and peace as the basis for peace negotiations and partly withdrew the Israeli positions in the 1980s.

On the one hand, Netanyahu found himself captured in the party commitments and on the other hand feared the disintegration of the coalition that had kept him in power. Thus, from the beginning, he moved ahead opposing the Oslo peace process stubbornly. However, he inevitably had to the resume the peace negotiations under growing international pressure, especially from the United States, and after his talks with Arafat at the White House in January 15, 1997, he signed the agreement on redeployment in Hebron. In this Agreement, the principle of reciprocity was invoked for the first time. In Hebron Agreement, both Israel and the PA accepted commitments based on the principle of reciprocity. Israel agreed to perform the first part of a three-stage withdrawal as it had been mentioned in Oslo 2 by the end of March 1997, release Palestinian prisoners and begin talks on topics of the transitional period, including the establishment of an airport in Gaza. In contrast, the Palestinians also accepted tasks, such as completing the process of revising the Palestinian National Charter, dealing with terror and violence, preventing incitement and hostile propaganda, transferring suspects and confiscating illegal weapons ${ }^{27}$.

According to Hebron Agreement, Israeli forces left parts of Hebron, but because of the stubborn stance followed by Netanyahu, agreements on the process of withdrawal in accordance with the division of the Oslo agreements, was not implemented in practice and the peace process stagnated once again. Once again diplomatic efforts for the restoration of the peace process began by regional and international actors, which eventually led to the signing of the agreement Wye River Plantation. The agreement was signed by Prime Minister Benjamin Netanyahu and Yasser Arafat on October 23, 1998 in the presence of Bill Clinton, in Maryland, United States. Israel pledged to withdraw from 13 percent of Palestinian land in the West Bank and deliver the areas to the Palestinian Authority. Yasser Arafat was committed to confront with armed Palestinian militants and supply the security of Israeli civilian under a work plan. Other items agreed upon included the release of 750 Palestinian prisoners by Israel, removing the destruction of Israel from the PLO Charter, the establishment of a Palestinian airport in Gaza, opening the road for Palestinians between the West Bank and the Gaza Strip crossings as well as taking the third stage of the negotiations on the withdrawal of the Israeli army from the West Bank ${ }^{28}$.

This agreement was stopped by the Israeli party after coming parts of its provisions into force, including the withdrawal of Israeli forces from the 7 percent of the West Bank and the release of 250 Palestinian prisoners, under the pretext of Authority's non-compliance with its obligations. The Israeli Parliament also added conditions for its implementation. The Parliament Decided to hold the general election in late spring 1999. Netanyahu refused to implement Phase II and III of this agreement, therefore, the implementation of the agreement was suspended at least until holding the general election and selection of the new prime minister. ${ }^{29}$

Like the Oslo agreements, the agreement also had a lot of inherent weaknesses. The agreement was based on reciprocity. But fundamental weaknesses such as lack of supervision and will for the conclusion of the agreement, along with the mentioned reasons led to the failure of the Maryland agreements. However, the lack of commitment by the parties to the material and spirit of this agreement that was based on step by step trust was not ineffective in breaking the agreement. On the one hand, shifting the date and time of the redeployment of Israeli forces, lack of releasing the political prisoners according to the agreement etc. by Israel and on the other hand, lack of the Palestinian National Covenant revision, creating insecurity on the borders of Palestine etc. were

\footnotetext{
${ }^{26}$ Kootab, Daoud, 15 reason that the disgraceful Oslo Accords cause violation of the Palestinian people's rights 2013, Young Journalists Club website, 29 Mordad 1393, available at:

http://www.yjc.ir/fa/news/4553438/15(14:10).

${ }^{27}$ Bayat, Nasser, Netanyahu's positions and Practice on the Middle East Peace Process and Practice, Journal of Regional Studies, Issue III, 2000, pp. 86-85

${ }^{28}$ Bina, , y Full text Plantyshn Agreement, Middle East Quarterly, Issue II, III, 1998, pp. 182-171.

29 .Barzegar, Kayhan, assessment of Likud positions on Syria peace talks - Israel, Regional Studies, Issue 4, 2000, Page 4.
} 
among the most important violations of the commitment by the parties. ${ }^{30}$

\section{- Camp David the second negotiations}

The victory of Ehud Barak, head of the Labor Party, in Israeli elections in May 1999, prompted a wave of optimism in some political and press circles of the Arab world. those who knew Netanyahu's actions destroying all the achievements of the peace process during three years of his rule, waited for the results of the elections and the victory of Ehud Barak, with the notion that Barack will return to the path of peace and moves it to its final destination. But Barak announcing four fixed principles as the framework for peace talks, turned all these ideas into disappointment. He announced the his fixed principles as follows:

Jerusalem will remain the capital of the state of Israel forever;

We will never to go back pre-June 1967 borders;

No army will be allowed in the West Bank; and

The bulk of Jewish settlements in the West Bank will remain within the Israeli sovereignty. ${ }^{31}$

Barak government announced that the Middle East peace process implementation will be possible by the Wye River Plantation agreement. But Barak insisted on changing the timing of the implementation of the Wye Plantation agreement, and placed the PA in a difficult situation. Under the agreement, the second phase of withdrawal $(5 \%)$ of the West Bank land should had been implemented six months ago, but Barak insisted that the second stage of withdrawal will be implemented in September 1999 and third stage will be completely ruled out and be included in final negotiations with the Palestinians. ${ }^{32}$

\section{- Third Course}

\section{Ariel Sharon}

Sixth February, 2000 election was held two years ahead of schedule after the resignation of Prime Minister Barak due to failure of talks with the Palestinians. In this election, Sharon was overcame Barack with a significant difference. After being assigned as Prime Minister, Sharon announced the situation of Israel insecure calling Israel's citizens insecure. He announced the establishment of security and reaching a situation in which Israeli citizens feel secure as his first goal. To deal with this situation, he asked for the co-operation of competing political parties with each other and called national unity of Israel a necessity. ${ }^{33}$

Sharon's strategy, like other Likud leaders to compromise with the Palestinians, was peace against security. Regarding the causes of negotiations, this strategy was rigid. In this context, Sharon, in one of his election speeches, stressed the issue of Israel's security as the first priority of the regime. ${ }^{34}$

\section{- Confidential Geneva Convention}

Due to difficulties in the way of implementing the "road map" ${ }^{35}$ peace plan other methods were attempted to be replaced. The result of these efforts was the signing of the Geneva Convention. The 50-page treaty was the result of two and a half years secret negotiations led by Yossi Beilin, former Israeli Justice Minister, and Yasser Abed Rabbo, former Palestinian information minister. In December 2003, the two sides signed the unofficial peace plan in Geneva. Shared sovereignty of Jerusalem and annulment of the Palestinian right of return were the key points of the project. The event was organized by the Government of Switzerland, attended by Jimmy Carter and Lech Walesa (ex-president of Poland). This peace initiative was supported by Europe, as well as verbal support of Kofi Annan, Secretary-General of the United Nations. ${ }^{36}$

By early December protests were held against the treaty with the participation of members of Hamas ${ }^{37}$ and Islamic Jihad in the northern Gaza Strip. The treaty, which aimed to create two states, Israel and Palestine, had

\footnotetext{
30 Anonymus,1998, Wye River Memorandum, 20 agust 2014, website palestine facts, Available at: http://www.palestinefacts.org/ pf_1991to_now_wye_agreement_1998.php (13:15)

${ }_{31}$ Mohtadi, Mohammad Ali, an independent Palestinian state, a distant mirage, Middle East Quarterly, Issue A, 1378, p2

${ }^{32}$ Mohamed, Barack and future Middle East peace process, the Middle East Quarterly, Issue Tuesday, 1999

${ }^{33}$ Ghassemi,Hakem, The Israeli government imposed artificial nature ,A permanent security crisis, Journal of Regional Studies, Issue A, 2003, p.

${ }^{34}$ Ghassemi,Hakem, Regional impact of the new Israeli government policy, defense policy magazine, Issue 2, 1997, pp. 100-

35 Ephron, Dan, Sharon Statement Brings Storm of Criticism, Boston Globe, 28 May 2003.

${ }^{36}$ Anonymous, The Geneva Accord, 2003, website Palestinian Peace Coalition: Geneva Initiative, 11 August 2014; Available at URL: http:// www. geneva-accord.org/ mainmenu/ english (10:23).

${ }^{37}$ Ben Simon, Daniel, Ha'aretz, 2 May 2003, Available Online At: http://www.comeand see.co.il/print.php?sid=450(19:47)
} 
predicted almost complete withdrawal of Israel from the West Bank and Gaza and the recognition of Israel by the Palestinians. In addition, the Palestinians had abandoned the right of return of millions of refugees who have left their land or were expelled from it in previous wars, given that this was a violation of international law. Unlike the roadmap, the plan was not aimed at a temporary cease-fire, but it was a comprehensive solution to assess all issues, including Jerusalem, settlements and refugees. The official road map peace plan, supported by America, was first to create conditions in which a political agreement was possible. In contrast, first the Geneva Convention predicted a political agreement between the conflict parties, which can finally lead to peace. However, Israel rejected the plan completely and described it as an attempt to undermine the regime. In addition, because Yasser Arafat's senior security consultant attended at the event in Geneva, but the Palestinian leadership refused to declare supporting it and considered it impractical. ${ }^{38}$

\section{- Sharm el-Sheikh the second meeting}

The second summit began in Sharm el-Sheikh on 8 February 2005 with the presence of Ariel Sharon, the Israeli prime minister, Mahmoud Abbas, Mubarak and King Abdullah to find a way to end the second four-year intifada. During the intifada, none of the parties were willing to negotiate, until Yasser Arafat died in November 2004 suspiciously and in January 2005 Mahmoud Abbas was elected as Palestinian Authority president. His actions in preventing Palestinian attacks caused Sharon's willingness to negotiate. At the summit, after meetings between Sharon, Mubarak, King Abdullah and Abbas, the progress of the peace process was agreed upon in accordance with the road map. Sharm el-Sheikh summit ended the second Intifada officially. ${ }^{39}$

\section{The Annapolis conference}

The Annapolis conference is a peace conference organized on 27 November 2007 at the Naval Academy in Annapolis, Maryland, America with the presence of the leaders of the Palestinian territories, Israel, representatives from Arabic countries and hosted by the United States of America. The Middle East peace conference, was the first comprehensive and serious negotiations to achieve a comprehensive peace in the Middle East that was held since 2000 to that date. Apart from the members of the quartet group of the Middle East peace known as the "Quartet" that includes the United States of America, Russia, the UN and Europe, had Jordan, Egypt, Saudi Arabia, Syria, Lebanon and Qatar among the invitees and participants.

Palestinian Authority President, Mahmoud Abbas, hoped to get the final peace treaty between Israel and the Palestinians signed less than six months after the end of the the peace conference. On the other hand, Syrian President, Bashar Assad said his country will participate in the Middle East peace conference only if the subjects considered by Syria were put as the agenda, referring to the issue of restoring the strategic area of Golan Heights captured in the Six-Day War by Israel in 1967. Mahmoud Abbas and Ehud Olmert met on a weekly basis from June 2007 and had direct negotiations and reached agreements on general grounds. In early October, Abbas declared the demands of the Palestinians and said the Palestinian side wants a Palestinian state including the Gaza Strip and the West Bank.

After that Mahmoud Abbas, raised other demands and said that the conference should address six main challenges between the Palestinians and Israel that would include the issue of Jerusalem division, Palestinian refugees and their right of return, borders, Jewish settlements, water and security issues. The two sides hoped to reach an important agreement by the end of November and, if the agreement was acceptable to both sides, Mahmoud Abbas would hold a referendum among Palestinians on the agreed conditions and Palestinians' achievements. The important issue of Jerusalem division was also agreed to be the conference agenda, but Hamas once again rejected the compromise conference. After several days of negotiations, the meeting finally issued a statement according to which it was decided that by the end of 2008, the two sides agree on arrangements for a lasting peace.

In the summit Israel accepted that Golan was Syrian and declared its readiness to establish an independent Palestinian state. Apparently many participants, evaluated that the conference was a major achievement for solving the chronic crisis in Palestine; however, in parallel with the passage of time, little by little, a lot of views changed and hopes arose in Annapolis turned to despair. Then there was a division between Fatah and Hamas. Egyptian-brokered ceasefire between Hamas and Israel in 2008 lasted from 19 June and 19 December. The

\footnotetext{
${ }^{38}$ BBC Middle East peace process from 1967 to the present, 2013, the BBC news website, 22 August 2014, available at: www.bbc.co.uk/persian/world/2013/07/130730_an_middle_east_peace_process (14:10).

39 Oliver, Mark, Sharon and Abbas agree ceasefire, 2005, website the Guardian, 7 April 2014; Available at URL: http://www.theguardian.com/ world/ 2005/ feb/08/israel4 (16:45).
} 
failure of the cease-fire in Gaza on 27 December 2008 resulted in many crimes in Gaza. ${ }^{40}$

\section{Negotiations after the Gaza war}

By late 2009, the White House offered to host a trilateral negotiation between Obama, Netanyahu and Mahmoud Abbas to resume the Middle East peace talks. Direct negotiations between Israeli and Palestinian parties stopped after the start of Israel's military attack on the Gaza Strip in 2008. After that, the two sides began indirect talks brokered by America. In line with Obama government's efforts to start direct negotiations between Israel and Palestine, Hillary Clinton, tried for months to bring both sides to the negotiating table and finally succeeded with the help of Jordan and Egypt to convince the unhappy Palestinians to return to the negotiations. The purpose of the negotiations was to determine a framework for a final deal within a year. The goal of direct negotiations was to official end the conflict between the both sides using the two-state solution. Hamas and Lebanon's Hezbollah never recognized the talks.

Israel feared that in the case of concluding a final agreement, Hamas and Hezbollah act harshly. On the other hand, Israeli leaders announced that until the Palestinians do not recognize Israel as a Jewish state, they will reject any possible agreement. In April 2012, Mahmoud Abbas sent a letter to Netanyahu and expressed his willingness to resume talks under the conditions of freezing settlements in East Jerusalem and accepting the 1967 borders as the basis of the two-state solution. Netanyahu responded Abbas in less than a week and officially recognized the right of Palestinians to an independent state for the first time. Then in 2013, a few weeks of negotiations between representatives of Hamas, Israel and the Palestinian Authority did not avail. On 17 July the same year, John Kerry proposed a new political framework for talks with economic incentives for Palestinians and security guarantee for Israelis, but the Palestinians rejected it. However, two days later, Kerry said the two sides had concluded to resume direct negotiations, while Hamas denied the news and said that Mahmoud Abbas has no legitimacy to negotiate in the name of Palestine. It seems that this time the White House's efforts by John Kerry to conclude negotiations will be fruitless, because Israel is not willing to recognize the legitimate demands of the Palestinian people and on the other militant groups like Hamas are not willing to give up their multi-year aspirations and deal with the occupying Zionist regime. ${ }^{41}$

In 2014, once again severe clashes occurred between Hamas and Israel in Gaza causing many casualties and few truce tried to prevent it from continuing. But the truce was constantly violated. This truce was obtained while the two sides tried to find a long-term solution through indirect talks in Egypt. Egypt had presented a new proposal for a permanent agreement that included the Palestinians' demand to end the blockade of Gaza by Israel and Egypt. However, Israel wanted Gaza to become disarmament, and it was not clear whether this was considered in the proposal or not? Meanwhile, a spokesman for Hamas in Gaza said that disarmament is not an option. ${ }^{42}$

On the other hand, the Middle East peace talks that brokered by America aiming at the Israeli-Palestinian two-state had begun, was faced with a serious crisis. Palestinians, who knew the West Bank settlement freeze as a precondition for continuing the talks, announced that negotiations will not continue. On the other hand, Israel, suspended the amnesty and release of Palestinian prisoners detained in Israeli prisons and announced new settlement projects. In addition, Palestinians applied in different international institutions and agreements. America and Israel treated the Palestinian Authority's attempt in recognizing the Palestinian state outside the Middle East peace talks and this increased the tensions and disputes between them. ${ }^{43}$

Finally, on November 29, 2012, following the resolution of the UN General Assembly, Palestine could upgrade its position in the organization his status from "observer entity" to "non-member observer state "with 138 aye against 41 nay and nine abstains. Three of the five permanent member states of the Security Council, namely France, Russia and China voted for Palestinians, America refused it and Britain abstained. Israel, Canada, Czech Republic, Marshall Islands, Micronesia, Nauru, Palau and Panama were also among other countries that refused the Palestinian demand.

The following is evident in the text of the resolution adopted by the UN General Assembly:

Palestine is recognized as an non-members observer state of the United Nations and the Security Council is

\footnotetext{
${ }^{40}$ Young Journalists Club, comprehensive overview of the history of failed peace talks, 2013, young journalists club website, 16 July 2014 , available on the address: www.yjc.ir/fa/news/4486735(17:22)

41 The same

42 Deutsche Welle, agreement between Israel and the Palestinians to renew the truce, 2014, Deutsche Welle Web site, 13 Persian date Mehr 2014, available on the address:http://dw.de/p/1CuSU(22:20)

${ }^{43}$ Deutsche Welle, a meeting of Israel and the Palestinians to renew peace talks, in 2014, Deutsche Welle Web site, 2nd of Khordad 2014, available on the address:http://dw.de/p/1BjKh(15:26
} 
asked to look the Palestinians' demand introduced in September 2011, asking the council to agree with full membership of Palestine to the United Nations in a positive way;

In this resolution, the necessity of fair settlement of the Palestinian refugee problem and a complete halt to Israeli settlements in the Palestinian territories, including East Jerusalem, is emphasized;

The resolution is calling for the recognition of Palestinian rights framework and stresses that peace must be established in a fair manner and "occupation that started in 1967", end;

The resolution stresses that the negotiations and the dialogue begin between the two sides to resolve disputes in a fair, permanent and comprehensive and "two-state solution together" form.

\section{Conclusion}

According to customary international law, Israel had status of occupying power, in the occupied territories. By all explanation and emphasis of four Geneva conventions and its additional protocols based on transferring part of the civilian population of the occupying state to occupied territory by that government، expulsion or transferring all or part of the population of the occupied territory, unjustified delays in the return of prisoners of war or civilians in the country, racism and same acts, attack on historic buildings, works of art or holy places, gross violations of the Geneva Conventions and protocols of accession.

Therefore, Israel is obligated to withdraw to borders of pre-1967 in terms of customary international law and settlements must be stopped, and right of return of Palestinian refugees to their homeland and paying compensation to them must be accepted. According to Article 1 of the Covenant on Civil and Political Rights and the Covenant on economic, social and cultural rights that explicitly support right of self-determination, conditions for creating an independent Palestinian state provided. Due to the Court advisory opinion regarding retaining wall in 2003, the Court points out, lands located between Jordan and the former eastern boundary are under the mandate of Palestine has been occupied by Israel in 1967 during the armed conflict between Israel and Jordan. According to customary international law, Israel had status of occupying power. The next events in these territories did not cause any change in this situation. The Court concludes that all these territories (including Eastern Jerusalem) remained as the occupied territories and Israel, has continued to its occupying power. Accordingly, some plans and agreements the have been proposed and signed. The historical review of the peace plans and agreements related to the conflict of Palestine, indicates that nearly seventy years of this conflict, not only no concrete results have been created toward the peace, it sometimes leads to distrust and creating a negative psychological burden among negotiators. In fact, string of this endless conflict is based on the same procedure of the war, then peace negotiations have continued and the current round continues. In Arabic and African countries, such Egypt's revolution that took place might be undergoing many changes. However, with the wave reduction, the possibility also to be forgotten. Unfortunately, most of the proposed proposals has faced refused

by one of the parties . Generally Israel only partially agree with US plans and does not accept plans of other countries and practically has made a monopoly for America. On the other hand, American and European plans are not accepted and will be mocked by Hamas in Palestinian. In addition, negotiations leading to this contracts have not been away from the political and legal aphtous ulcers. Form the political side to these plans and contracts, we will face with sabotage of the Israelis negotiators sabotage. The main reason for sabotage in the first place, is the displacement of political power between parties of left and right in Israel. In the second place, is in sense of insecurity that is common among all Israeli governments in a different level. Besides these variables, the other issue of is in not to achieve the sustainable peace, lack of unity among Palestinian groups and the uncertainty of their strategy against Israel. From the legal aspects, the peace agreements have gaps and ways to escape. Lack of a clear framework that includes all the factors in peace, lack of guarantee and weakness of contract enforcement, which results in lack of adherence to the principles and provisions of the contract, Lack of accurate and powerful system of monitoring the implementation of contracts, lack of legal mechanisms for some of the most disputed issues including issues of Jerusalem, the separation wall, refugees and ... caused the peace agreements do not remain and their weak legal foundation was one of the main reasons. The only real answer, is the existence of a United Nations force in the region to facilitate the elimination of the occupation in all its forms and helping the Palestinians to achieve a stable state under a democratically elected government. Finally, it seems achieving a sustainable peace, will remain elusive until there is no further determination from the Palestinian-Israeli interests of the group and Palestinian internal parties and comprehensive plan and contract that includes important issues between the two sides and supported by the international community. 


\section{References}

Anonymous, The Geneva Accord, 2003, website Palestinian Peace Coalition: Geneva Initiative, 11 August 2014. Retreived from http:// www. geneva-accord.org/mainmenu/english (10:23).

Anonymus, Wye River Memorandum, 1998, 20 agust 2014, website palestine facts. Retreived from http://www.palestinefacts.org/pf_1991to_now_wye_agreement_1998.php

Ben Simon, Daniel, Ha'aretz, 2 May 2003. Retreived from http://www.comeand see.co.il/print.php?sid=450

Both Quotes Are in Ali Abunimah, "Who's Afraid of the Road Map?" Daily Star (Beirut), 2 May 2003.

Ephron, Dan, Sharon Statement Brings Storm of Criticism, Boston Globe, 28 May 2003.

Flamhaft, Z. (1996). Israel on The Road to Peace. West view Press, United State.

Knesset, A Performance- Based Roadmap to a Permanent Two- State Solution to the Israeli- Palestinian Conflict, 2003, website knesset, 4 September 2014. Retreived from http://knesset. gov.il/ process/ docs/ roadmap eng. htm (16:37)

Oliver, Mark, Sharon and Abbas agree ceasefire, 2005, website the Guardian, 7 April 2014. Retreived from http://www.theguardian.com/ world/ 2005/ feb/08/israel4 (16:45).

Statement From Prime Minister's Bureau, as Released by Israel's Government Press Office, Israel Accepts 'Steps' of Road Map, Qualified by Remarks, Israel Insider, 25 May 2003. Retreived from http://www.israelinsider,com

Venkateshwar Rao Jr., Parsa, India's Right- Wingers Woo Jewish Lobby, Daily Star (Beirut), 20 May 2003.

Whitbeck, John, The Road Map, Daily Star (Beirut), 4 May 2003.

\section{Copyrights}

Copyright for this article is retained by the author(s), with first publication rights granted to the journal.

This is an open-access article distributed under the terms and conditions of the Creative Commons Attribution license (http://creativecommons.org/licenses/by/4.0/). 